\title{
ZMIANY I INNOWACJE W ORGANIZACJI WARUNKIEM BUDOWANIA POZYCJI KONKURENCYJNEJ WE WSPÓŁCZESNYM OTOCZENIU
}

\begin{abstract}
Z a r y s t r e ś c i: Artykuł ma na celu pokazanie roli i znaczenia zmian i innowacji we współczesnej organizacji. Współcześnie funkcjonujące przedsiębiorstwa muszą budować swoją pozycję konkurencyjną wykorzystując różnego rodzaju atuty. Jedną z możliwości jest wdrażanie w przedsiębiorstwie zmian i innowacji, akceptowanych przez pracowników. Bez takich działań funkcjonująca dziś organizacja nie może zabiegać o liczącą się konkurencyjną pozycję.
\end{abstract}

S ło w a k l u c z o w e: zmiana; innowacja; konkurencyjność; otoczenie.

Klasyfikacja JEL: L21.

\section{WSTĘP}

Współczesna gospodarka ma wymiar globalny i wiąże się z licznymi, gwałtownymi przemianami, zachodzącymi na całym świecie. Przyczyną tych przeobrażeń jest wzrastająca konkurencja, pojawiające się nowe rynki zbytu, a także odmienne wymagania i preferencje konsumentów. Otoczenie zewnętrzne wywiera ogromny nacisk na firmy, wymuszając wprowadzanie nowych, innowacyjnych metod i rozwiązań w różnych sferach działalno-

* Adres do korespondencji: Krystyna Serafin, Uniwersytet Ekonomiczny w Katowicach, Wydział Zarządzania, ul. Fitelberga 22a, 40-588 Katowice, e-mail:krystyna. serafin@gmail.com. 
ści: produkcji, technologii, dystrybucji, marketingu, sprzedaży. W związku z tym przedsiębiorstwa muszą się rozwijać, doskonalić, ulepszać swoje możliwości produkcyjne, wprowadzać nowe, innowacyjne technologie, bacznie obserwować konkurencję i jej poczynania. Wdrażając różnego rodzaju zmiany i innowacje, w większym lub mniejszym zakresie, firmy podejmują walkę o pokonanie konkurencji i utrzymanie swej pozycji na rynku, a także o zaspokojenie potrzeb i oczekiwań klientów.

\section{ISTOTA I ZNACZENIE ZMIAN W ORGANIZACJI}

Działalność każdej firmy wiąże się nieodłącznie ze zmianami organizacyjnymi. Zmiany te powiązane są z nowinkami technicznymi i technologicznymi. Powodzenie zmiany w dużej mierze zależy od umiejętnej komunikacji z pracownikami, gdyż brak komunikacji w przedsiębiorstwie może być odbierany jako lekceważenie i może budzić nieufność. W wielu firmach częste zmiany są postrzegane jako wynik błędnego postępowania kadry kierowniczej, podejmowania złych decyzji i niedorównywania zmianom zachodzącym w otoczeniu [Grouard, Meston, 1997, s. 13]. W terminie ,zmiana” występują dwa wzajemnie uzupełniające się wymiary: treść i proces [Błaszczyk, 2005, s. 262]:

- treść - to rezultat zmiany odnoszący się do zasobów rzeczowych i ludzkich, techniki i technologii, a także do wszelkich relacji społecznych, politycznych, bądź gospodarczych;

- proces - to sposób dokonywania zmiany, który jest ściśle powiązany z metodami i technikami ich wykonania.

Powyższe wymiary są nierozdzielne, gdyż realizacja procesu zmian ma sens tylko ze względu na ich treść, ma bowiem doprowadzić do założonych celów. Natomiast realizacja treści nie ma szans, jeśli proces dochodzenia do jej osiągnięcia nie jest adekwatny do założonych celów. Pojęcie „zmiana” ma zatem charakter [Mikołajczyk, 2002, s. 10]:

- czynnościowy (aktywny) - polegający na podjęciu akcji mającej na celu dokonanie zmiany;

- rzeczowy - jakim jest wynik działań zmieniających dotychczasową rzeczywistość.

Termin „zmiana” często bywa używany jako synonim innowacji, transformacji, ewolucji społecznej, bądź dynamiki organizacyjnej, co nie zawsze jest zasadne. Zdaniem Ewy Masłyk-Musiał, aby jakieś zjawisko mogło być nazwane zmianą, musi ono być [Masłyk-Musiał, 2003, s. 29]: 
- percypowane (postrzeżone) - zakłada intencjonalność tego, co nowe i inne, umożliwia opis cech danego zjawiska; postrzeganie zmiany w organizacji może mieć różny charakter i zależeć od cech indywidualnych, grupowych i organizacyjnych;

- empiryczne - zmiany mogą być badane w celu udowodnienia, że w organizacji coś się zmieniło; mowa tutaj o zmianach ważnych, decydujących o sukcesie firmy i jej pozycji konkurencyjnej na rynku; są to zmiany związane ze strategią firmy, wymagające modyfikacji wzorów zachowań jej interesariuszy, polegające na powstawaniu nowych relacji między strukturą a kulturą firmy;

- planowe - zmiany muszą być w pewnym stopniu sterowalne; polegają na próbie przewidzenia ich użyteczności dla organizacji i ocenie z punktu widzenia założonego wyniku programu zmian; projekty zmian muszą być monitorowane, oceniane i korygowane.

\section{PRZYCZYNY ZMIAN W ORGANIZACJI}

Przyczyn zmian w organizacji należy dopatrywać się w niedostosowaniu do zmieniających się warunków otoczenia, zarówno zewnętrznego, jak i wewnętrznego.

Do zmian wynikających z przyczyn otoczenia zewnętrznego zalicza się:

- zmiany w zakresie prawa (handlowego, podatkowego, pracy, ubezpieczeń, transportu, bezpieczeństwa itd.);

- zmiany naukowo-techniczne (automatyzacja produkcji, komputeryzacja, nowe technologie, nowa organizacja pracy itd.) będące w zasięgu możliwości wdrożenia w organizacji;

- zmiany rynkowe - dostępność surowców, kapitału, kooperantów, wzrost potencjału pieniężnego ludności oraz rozwój konkurencji;

- zmiany społeczno-kulturowe (nowe normy wartości, zapotrzebowanie na nowoczesne produkty, doskonalsze lub nowe usługi itd.) pod wpływem wzorców z państw sąsiednich.

Do przyczyn zmian generowanych $w$ otoczeniu wewnętrznym należą:

- rozwój organizacji (powstanie, rozkwit, stabilizacja),

- zaburzenia procesów samoregulacji w organizacji,

- produkcja wyrobów, na które nie ma już zbytu,

- nadmierne zgromadzenie wyrobów, które nie są poszukiwane na ryn$\mathrm{ku}$, 
- starzenie się parku maszynowego,

- nadmierne lub niepotrzebne do produkcji zapasy surowców,

- zaburzenia $\mathrm{w}$ rozliczeniach finansowych $\mathrm{z}$ otoczeniem i pracownikami,

- odchodzenie specjalistów i pracowników,

- poczucie beznadziejności wśród pracowników i kierownictwa.

\section{RODZAJE I MOTYWY ZMIAN}

Podział zmian organizacyjnych odgrywa rolę porządkującą oraz ułatwia scharakteryzowanie podejmowanej zmiany i przewidzenie przyszłych jej skutków. Pozwala to na ograniczenie w znacznym stopniu wystąpienia ryzyka niepowodzenia. Wyróżnia się dwa podejścia do klasyfikowania zmian [Zarębska, 2002, s. 52]:

- podejście jednowymiarowe - dzieli zmiany na określone grupy na podstawie nasilenia pojedynczej wybranej cechy (czas trwania, relacja czasowa między zmianą środowiska a zmianą organizacji, zasięg i głębokość);

- podejście wielowymiarowe - rozpatruje zmiany pod wieloma względami naraz, zmiana traktowana jest jako zespół cech, których kombinacja daje określony typ zmiany organizacyjnej i które łącznie odzwierciedlają sens tego pojęcia.

Zofia Mikołajczyk dokonała podziału zmian na podstawie dwóch podstawowych kryteriów - zasięgu zmian i charakteru zmian [Mikołajczyk, 2002, s. 18].

Ze względu na zasięg zmiany dzielą się na:

- zmiany stosunkowo niewielkie - działanie nie wywołuje trwałych efektów, odnosi się do zjawisk lokalnych dotyczących niewielkiej liczby osób; mogą one wpływać na codzienne funkcjonowanie przedsiębiorstwa, a ich skutki mogą się kumulować nawet wtedy, gdy zachodzą w różnych jego podsystemach i na różnych poziomach zarządzania; takie zmiany są rezultatem stosunkowo prostych przedsięwzięć organizacyjnych;

- zmiany o szerszym zasięgu i intensywności - odnoszą się do określonych elementów składowych przedsiębiorstwa, ich rezultaty są trwałe, poszerzają wprowadzone zmiany o inne elementy;

- zmiany powstałe w wyniku działań złożonych (kompleksowych) zaprogramowane na długie okresy, stanowią przedmiot strategii 
przedsiębiorstwa; do ich cech charakterystycznych należą: szeroki zasięg, dostosowanie do specyfiki sytuacji, charakter ewolucyjny, spójność wewnętrzna i ogólna; jest to określone postępowanie w zarządzaniu przedsiębiorstwem, które polega na stopniowym wprowadzaniu przedsięwzięć skomplikowanych, rozłożonych w czasie realizowania celów strategicznych.

Ze względu na charakter zmiany dzielą się na:

- zmiany innowacyjne - przedsiębiorstwa muszą znacznie bardziej intensywnie tworzyć i rozwijać własny potencjał wytwórczy po to, aby działać szybko, elastycznie i efektywnie; rozwój i konieczność dostosowania się do wymagań otoczenia powodują wprowadzanie innowacji $\mathrm{w}$ różnych sferach funkcjonowania organizacji; mowa tutaj nie tylko o innowacjach technicznych i technologicznych, ale i społeczno-organizacyjnych, które pozwalają na szybkie reagowanie i dostosowywanie możliwości własnych organizacji do wyzwań, jakie stawia sytuacja w otoczeniu;

- zmiany adaptacyjne - polegają na doskonaleniu systemu, ale nie prowadzą do zmiany jego charakteru; wynikają z ekonomicznej konieczności rozwoju, poprawy dotychczasowego funkcjonowania, podniesienia jego efektywności; zmiany adaptacyjne stosowane są w dwóch pierwszych przedziałach zmian pod względem ich zasięgu, ale w zależności od charakteru obiektu, w którym są one realizowane, mogą mieć różną treść i wykorzystywać różne narzędzia badawcze;

- zmiany regresyjne - to zmiany o charakterze negatywnym, gdzie krańcowym rezultatem tych zmian jest bankructwo i likwidacja przedsiębiorstw, wzrost bezrobocia i ogólnego niezadowolenia społecznego oraz wszelkiego rodzaju patologii społecznych w skali całego kraju; zmiany te są konsekwencją gwałtownych, o nieoczekiwanym zasięgu, zmian $\mathrm{w}$ otoczeniu, ale w dużej mierze są one zawinione przez same przedsiębiorstwa i ich kierownictwo; dowodzi to współzależności zmian w otoczeniu i przedsiębiorstwie, ale także ukazuje ogromne trudności w ich wprowadzaniu.

Ewa Masłyk-Musiał sklasyfikowała zmiany w nieco bardziej szczegółowy sposób [Masłyk-Musiał, 2003, s. 38]:

- ze względu na przyczyny:

- dobrowolne - organizacje zmieniają swoje formy, ponieważ dostrzegły nowe okazje w otoczeniu;

- wymuszone - zmiana jest następstwem trudności bądź kryzysów.

- ze względu na udział w zmianach: 
- partycypacyjne - zmiany są planowo ukierunkowane na większe zaangażowanie się pracowników w realizację strategii firmy;

- narzucone - zmiany wprowadzane odgórnie, mogą być odbierane przez pracowników jako wymuszenie i budzić większy opór; warunkiem skuteczności tych zmian jest wiarygodność kierownictwa firmy odpowiedzialnego za program zmian.

- ze względu na wysiłek włożony w przekształcenia i towarzyszące im ryzyko osiągania celów zmiany:

- zmiany adaptacyjne (dostrojeniowe) - zmiany powolne, realizowane w stosunkowo stabilnym otoczeniu;

- rewitalizacja - wymaga zmiany struktur, systemów i procesów; często przybiera formę agresywnej modyfikacji tych elementów i ekspansji, ale w ramach dotychczasowego terytorium działania;

- transformacja - duże zmiany powstające w odpowiedzi na ważne impulsy z otoczenia, np. polityczne, wyzwania technologiczne bądź globalna konkurencja; transformacja umożliwia ustalenie nowych standardów dla klientów;

- przewrót - duże zmiany w strategii przeprowadzane w krótkim czasie (do roku); ograniczony czas uniemożliwia wprowadzenie głębokich zmian kulturowych istotnych dla projektów zmian, co w połączeniu z możliwymi ograniczeniami finansowymi zmniejsza szansę odniesienia sukcesu.

Zmiany mogą być grupowane na podstawie kilku kryteriów jednocześnie, co przedstawia tabela 1 .

Tabela 1. Wielokryterialna klasyfikacja zmian

\begin{tabular}{|c|c|c|}
\hline Kryterium & \multicolumn{2}{|c|}{ Rodzaje zmian } \\
\hline Sterowalność & planowe & nieplanowane \\
\hline Taktyka zmieniania & dobrowolne & wymuszone \\
\hline Źródło zmian & zewnętrzne & wewnętrzne \\
\hline Skuteczność zmian & doskonalące & zubożające \\
\hline Czas trwania zmian & długotrwałe (do kilku lat) & krótkotrwałe (do kilku tygodni) \\
\hline Zakres zmian & duże, istotne, strategiczne & drobne, operacyjne, dostrojeniowe \\
\hline Inwencja & precedensowe & kontynuowane \\
\hline
\end{tabular}


Cd. tab. 1

\begin{tabular}{|c|c|c|}
\hline Kryterium & \multicolumn{2}{|c|}{ Rodzaje zmian } \\
\hline Styl zmieniania & partycypacyjne & narzucone \\
\hline Sposób zmieniania & skokowe (jednorazowe) & inkrementalne (“krok po kroku”) \\
\hline Kierunek zmian & z góry do dołu hierarchii & z dołu do góry hierarchii \\
\hline Powiązania zmian & transakcyjne (wewnątrz firmy) & $\begin{array}{c}\text { transformacyjne (w firmie } \\
\text { oraz między firmą i otoczeniem) }\end{array}$ \\
\hline
\end{tabular}

Źródło: E. Masłyk-Musiał, Organizacje w ruchu, Oficyna Ekonomiczna, Kraków 2003, s. 42.

\section{STRATEGIA WPROWADZANIA ZMIAN W ORGANIZACJI}

Do przeprowadzenia skutecznych zmian niezbędne jest posiadanie odpowiedniego przywództwa, wyposażonego w silne środki oddziaływania, a także zrozumienie faktu, że praktyczna realizacja zmiany zależy w szczególności od postaw ludzkich i ich troski oraz zaangażowania w sprawy firmy. Przeprowadzanie zmian wymaga zrozumienia kierunku rozwoju organizacji oraz roli personelu w dążeniu do jego realizacji.

Zdaniem Kurta Lewina zmiana jest połączeniem trzech następujących po sobie faz [Grouard, 1997, s. 72]:

- pobudzanie/rozmrożenie - polega na zburzeniu stabilności i równowagi dominujących postaw i zachowań; należy wziąć pod uwagę wszystkie zagrożenia dla ludzi, jakie mogą powodować planowane zmiany i opracować system zachęt, mający na celu doprowadzenie do ich akceptacji;

- transformowanie - inny sposób reagowania na nowe informacje;

- konsolidacja/ponowne zamrożenie - stabilizacja i utrwalenie zmian poprzez zakodowanie ich w świadomości pracowników organizacji.

W celu oszacowania wagi argumentów przemawiających przeciwko zmianom oraz nakłaniających do zmiany Kurt Lewin zaproponował tzw. „teorię pola" polegającą na [Armstrong, 2001, s. 104]:

- analizie plusów i minusów - elementami hamującymi mogą być reakcje osób, które uważają zmiany za zbędne lub traktują je jako zagrożenia; 
- określeniu kluczowych aspektów niezbędnych do przeprowadzenia procesu zmian;

- przedsięwzięciu działań wzmacniających kluczowe aspekty pozytywne i niwelujących skutki oddziaływań negatywnych.

Amerykańskie badania pozwoliły wyróżnić dwie podstawowe teorie wprowadzania zmian: twardą (E) i miękką (O). Teoria E ma na celu szybką poprawę wskaźników ekonomicznych, która uzasadniona jest koniecznością podnoszenia wartości giełdowej firmy. Łączy się ona z radykalnymi zwolnieniami w przedsiębiorstwie, głęboką restrukturyzacją oraz wykorzystaniem dużych nakładów finansowych. Wprowadzając tę teorię, menedżerowie starają się uprościć wszystkie struktury i systemy, sami ustalają cele, niechętnie korzystają z propozycji innych, nie liczą się ze zdaniem pracowników czy związków zawodowych, występują w roli dowódców. Teoria O dotyczy usprawnień organizacyjnych, a jej głównym celem jest tworzenie nowej kultury firmy i lepsze wykorzystanie potencjału ludzkiego poprzez szkolenia, refleksje i wprowadzanie stopniowych zmian. Przedsiębiorstwa stosujące tę koncepcję skupiają się głównie na stopniowym ulepszaniu organizacji, podnoszeniu poziomu jakości i produktywności, a także na zaangażowaniu pracowników w ten proces. Teorie E i O przedstawia tabela $\mathrm{nr}$ 2. Wiele przedsiębiorstw stosuje obie te koncepcje, jednak najlepszym sposobem jest stosowanie ich kolejno po sobie, gdyż jak wskazuje praktyka, teoria E musi być w pewnym momencie złączona z teorią O. Niewłaściwe zestawienie obu teorii może spowodować ogromne szkody dla organizacji [Beer, Nohira, 2000, s. 11].

Tabela 2. Podstawowe filozofie wprowadzania zmian

\begin{tabular}{|l|l|l|l|}
\hline $\begin{array}{c}\text { Wyznaczniki } \\
\text { zmian }\end{array}$ & \multicolumn{1}{|c|}{$\begin{array}{c}\text { Filozofia E } \\
\text { (twarda) }\end{array}$} & \multicolumn{1}{c|}{$\begin{array}{c}\text { Filozofia } \\
\mathbf{0} \text { (miękka) }\end{array}$} & \multicolumn{1}{|c|}{ Kombinacja E+0 } \\
\hline Cele & $\begin{array}{l}\text { maksymalizacja } \\
\text { kursu akcji }\end{array}$ & $\begin{array}{l}\text { rozwój możliwości } \\
\text { organizacyjnych }\end{array}$ & $\begin{array}{l}\text { zadeklarowana wola } \\
\text { przezwyciężenia } \\
\text { sprzeczności między } \\
\text { podnoszeniem kursu } \\
\text { akcji i doskonaleniem } \\
\text { organizacji }\end{array}$ \\
\hline Przywództwo & $\begin{array}{l}\text { odgórne forsowanie } \\
\text { zmian }\end{array}$ & $\begin{array}{l}\text { zachęcanie pracow- } \\
\text { ników do współ- } \\
\text { udziału }\end{array}$ & $\begin{array}{l}\text { wyznaczenie } \\
\text { kierunków na górze } \\
\text { i wykorzystywanie ini- } \\
\text { cjatywy pracowników }\end{array}$ \\
\hline
\end{tabular}


Cd. tab. 2

\begin{tabular}{|c|c|c|c|}
\hline $\begin{array}{l}\text { Wyznaczniki } \\
\text { zmian }\end{array}$ & $\begin{array}{l}\text { Filozofia E } \\
\text { (twarda) }\end{array}$ & $\begin{array}{l}\text { Filozofia } \\
0 \text { (miękka) }\end{array}$ & Kombinacja E+0 \\
\hline Priorytety & struktury i systemy & $\begin{array}{l}\text { kultura } \\
\text { przedsiębiorstwa, } \\
\text { postawy pracow- } \\
\text { ników }\end{array}$ & $\begin{array}{l}\text { jednoczesne wyko- } \\
\text { rzystywanie czynni- } \\
\text { ków „twardych” } \\
\text { oraz „miękkich” }\end{array}$ \\
\hline Procesy & $\begin{array}{l}\text { odgórne plany } \\
\text { i programy }\end{array}$ & $\begin{array}{l}\text { eksperymenty } \\
\text { i ewolucja }\end{array}$ & $\begin{array}{l}\text { plany z miejscem } \\
\text { na spontaniczność }\end{array}$ \\
\hline $\begin{array}{l}\text { Systemy } \\
\text { wynagrodzeń }\end{array}$ & $\begin{array}{l}\text { bodźce finansowe } \\
\text { jako źródło moty- } \\
\text { wowania }\end{array}$ & $\begin{array}{l}\text { motywacja wynika- } \\
\text { jąca z długofalowe- } \\
\text { go zaangażowania - } \\
\text { wynagrodzenie jako } \\
\text { jeden z czynników } \\
\text { motywacji }\end{array}$ & $\begin{array}{l}\text { bodźce finansowe } \\
\text { w celu wzmocnienia } \\
\text { zmian, ale nie jako ich } \\
\text { źródło }\end{array}$ \\
\hline $\begin{array}{l}\text { Wykorzystywanie } \\
\text { konsultantów }\end{array}$ & $\begin{array}{l}\text { konsultanci analizu- } \\
\text { ją problemy i przed- } \\
\text { kładają rozwiązania }\end{array}$ & $\begin{array}{l}\text { kierownictwo } \\
\text { znajduje własne } \\
\text { rozwiązania, korzy- } \\
\text { stając ze wsparcia } \\
\text { konsultantów }\end{array}$ & $\begin{array}{l}\text { konsultanci przekazu- } \\
\text { ją pewne umiejętno- } \\
\text { ści pracownikom }\end{array}$ \\
\hline
\end{tabular}

Źródło: M. Beer, N. Nohria, Kombinacja twardej i łagodnej filozofii zmian, „Zarządzanie na Świecie", 2000, nr 7, s. 12.

Planując zmiany w organizacji, należy dokładnie określić ich cele, etapy, ramy czasowe, a także systematycznie kontrolować wypełnianie założeń oraz rozpoznać występujące natężenie oporu i przyczyny jego występowania po to, aby zastosować odpowiedni model wdrażania zmian i ewentualnie go skorygować. Planowanie zmiany jest procesem złożonym, dlatego warto korzystać z usług firm konsultingowych posiadających ogromne doświadczenie w tej dziedzinie.

\section{INNOWACJE WE WSPÓŁCZESNEJ ORGANIZACJI}

Innowacje są głównym czynnikiem decydującym o sukcesie danej firmy na konkurencyjnym rynku. Polegają one przede wszystkim na opracowaniu przemyślanej strategii z precyzyjnie wyznaczonymi wskaźnikami i miernikami wyników oraz na dobrym zarządzaniu i dostosowywaniu tych strategii do bieżących potrzeb rynku. 
Cechą firm innowacyjnych jest odnalezienie się i przetrwanie w środowisku przez dostrzeganie nadarzających się okazji, a także zmiany stylu kierowania z zachowawczego na innowacyjny. Przedsiębiorstwa, które nie wprowadzają innowacji, szkodzą swojej pozycji rynkowej, gdyż nie są w stanie walczyć z konkurencją.

Przedsiębiorstwo innowacyjne to takie, które [Jasiński, 1992, s. 25]:

- prowadzi w szerokim zakresie prace badawczo-rozwojowe bądź dokonuje zakupów nowych produktów czy technologii;

- przeznacza na tę działalność stosunkowo wysokie nakłady finansowe;

- systematycznie wdraża nowe rozwiązania naukowo-techniczne;

- reprezentuje duży udział nowości w wolumenie produkcji i usług;

- stale wprowadza innowacje.

Przedsiębiorstwo innowacyjne to inteligentna organizacja, która stale generuje i realizuje innowacje, zyskuje uznanie u odbiorców ze względu na swój wysoki poziom nowoczesności i konkurencyjności oraz posiada umiejętność dostosowania sposobu zarządzania do konkretnego zadania [Sosnowska, Łobejko, Kłopotek, 2000, s. 13]. Do najważniejszych cech firmy innowacyjnej zalicza się [Jasiński, 1992, s. 11]:

- pomysłowość oraz skłonność do ciągłego wytwarzania innowacji,

- wykorzystywanie innowacyjnego potencjału firmy dla utrzymania wysokiej pozycji konkurencyjnej,

- perspektywistyczne myślenie i przewidywanie przyszłości,

- utrzymywanie stałego kontaktu z klientami w celu skutecznego poznania ich bieżących i przyszłych potrzeb,

- umiejętne dobranie zespołu twórców i innowatorów zapewniających wysoki poziom innowacyjności firmy,

- właściwy zakres informacji pozwalający na trafną ocenę konkurencji i rynku,

- umiejętność dostosowywania się do zmian i potrzeb rynku.

Współczesne firmy muszą być zatem otwarte na wszelkie nowości, dostrzegać problemy z różnej perspektywy, być wrażliwe na sygnały i wyzwania rynku oraz gotowe do wprowadzenia u siebie różnego rodzaju zmian.

\section{POJĘCIE INNOWACJI}

Termin ,innowacja” jest pojęciem wieloznacznym, trudnym do jednoznacznego scharakteryzowania i stosowania. Często bywa kojarzony 
z innymi bliskoznacznymi terminami, np. usprawnienie, modernizacja, nowatorstwo, twórczość, rozwiązania niekonwencjonalne. Aby właściwie zrozumieć zjawisko innowacji, należy skupić się na pojęciach najbardziej charakterystycznych i rozpowszechnionych.

Innowacja to idea, postępowanie lub rzecz, która jest nowa i jakościowo lepsza. Pojęcie to można postrzegać w dwóch zasadniczych aspektach: jako zmiany w sferze produkcji, prowadzące do nowych rozwiązań procesowych i powstania nowych produktów lub wszelkie procesy badań i rozwoju, zmierzające do zastosowania i użytkowania ulepszonych rozwiązań do techniki, technologii i organizacji [Brzozowski, Kopczyński, 2001, s. 181].

Innowacje to siła napędowa gospodarki. Innowacja to twórcza zmiana w systemie społecznym, gospodarczym, technice oraz przyrodzie; to rozwiązania zmieniające dotychczasowy stan rzeczy, wprowadzające nowości i mające twórczy charakter [Marciniak, 2000, s. 11]. Innowacje mogą być postrzegane jako kształtowanie oczekiwań konsumentów oraz ciągłe reagowanie na ich zmieniające się wymagania, zachowania i doświadczenia, sięgając po najlepsze talenty i zasoby dostępne na całym świecie [Krishnan, Prahalad, 2010, s. 12].

Innowacyjność można określić jako zdolność i motywację firm do ciągłego poszukiwania oraz wykorzystywania w praktyce wyników badań naukowych, nowych koncepcji, pomysłów, a także wynalazków. Za innowacyjne uważa się te przedsiębiorstwa, które tworzą, absorbują i zdobywają nowe produkty bądź usługi oraz te, które charakteryzują się zdolnością ciągłego adaptowania się do zmian zachodzących w otoczeniu [Janasz, Leśkiewicz, 1995, s. 70]. Zdaniem Wiesława Grudzewskiego i Ireny Hejduk [2001, s. 451] przedsiębiorstwa, które permanentnie wprowadzają innowacje i reagują na zachodzące $\mathrm{w}$ otoczeniu zmiany, osiągają wiele znaczących efektów, które często decydują o ich istnieniu na rynku. Dzięki innowacjom $\mathrm{w}$ firmie dochodzi do polepszenia i unowocześnienia procesów wytwórczych oraz podniesienia produktywności, wydajności i jakości pracy. Często ma miejsce także lepsze przystosowanie przedsiębiorstwa do otoczenia oraz podniesienie jakości wyrobów i konkurencyjności ich sprzedaży, zlikwidowanie barier oraz aktywizacja zasobów przez zwiększenie ogólnej sprawności i efektywności działania, usprawnienie organizacji i metod pracy, poprawa warunków bezpieczeństwa pracy, substytucja pracy żywej w następstwie lepszej organizacji i wyższej wydajności opartej na bogatszym i bardziej nowoczesnym wyposażeniu technicznym, a także zwiększenie zdolności eksportowych. 


\section{7. ŹRÓDŁA INNOWACJI}

Źródłem innowacji może być wszystko to, co tworzy określone pomysły, idee, projekty i staje się przyczyną poszukiwania bądź wynajdywania rzeczy nowych, podejmowania różnych przedsięwzięć, a także wprowadzania ich w życie i doskonalenia. Mogą to być wszelkiego rodzaju instytucje naukowo-badawcze, przedsiębiorstwa i ludzie, konferencje naukowe, publikacje fachowe, wystawy i targi, literatura patentowa i normalizacyjna. Źródłem innowacji może być to, co inspiruje człowieka do zmian, środowisko pobudzające procesy zmian, pozwalające człowiekowi kreatywnie reagować na zachodzące zmiany w otoczeniu.

Źródła innowacji dzielą się na wewnętrzne (endogeniczne) i zewnętrzne (egzogeniczne), przy czym zewnętrzne dzielą się na krajowe i zagraniczne [Janasz, Kozioł, 2007, s. 29]. Źródła wewnętrzne są najcenniejsze, korzystanie z nich jest najtańsze, a płynące korzyści są wielostronne i mają charakter kumulatywny, gdyż sumowanie się nawet drobnych usprawnień daje efekt synergiczny. Mają one dużą wartość motywacyjną, ponieważ umożliwiają rozwój indywidualności wielu ludzi w ich celowym działaniu. Do wewnętrznych źródeł innowacji firmy należą [Penc, 1999, s. 158]:

- pracownicy firmy,

- kadra techniczna i menedżerska,

- koła jakości,

- wyniki prac zaplecza badawczego i technicznego.

Źródłami zewnętrznymi krajowymi innowacji są:

- krajowe badania naukowe prowadzone przez wyższe uczelnie,

- granty finansowane,

- badania naukowe i techniczne prowadzone przez instytuty branżowe,

- biura projektowe,

- ośrodki doświadczalne,

- przedsiębiorstwa innowacyjne.

Źródłami zewnętrznymi zagranicznymi innowacji są:

- zagraniczne zaplecze badawczo-rozwojowe,

- organizacje zajmujące się transferem wiedzy i technologii,

- import maszyn i urządzeń,

- zakupy licencji,

- zakupy usług,

- alianse strategiczne,

- franchising. 
Peter Drucker przedstawił siedem podstawowych źródeł okazji do innowacji, które podzielił na dwie grupy [Drucker, 2004, s. 39]. W skład pierwszej grupy wchodzą cztery źródła znajdujące się wewnątrz przedsiębiorstwa bądź sektora:

- to co niespodziewane - niespodziewany sukces, niespodziewana porażka, niespodziewane wydarzenie zewnętrzne;

- niezgodność między rzeczywistością a wyobrażeniem o niej;

- potrzeba procesu - wiele innowacji o charakterze organizacyjnym ma swoje podłoże w potrzebie zmiany np. standardowych procesów produkcji czy świadczenia usług;

- zmiany w strukturze rynku lub w strukturze branży - zmiany, które wszystkich zaskakują.

W skład drugiej grupy wchodzą 3 źródła zmian dokonujących się poza przedsiębiorstwem lub sektorem (zewnętrzne):

- demografia - jest silnym bodźcem wpływającym na działalność przedsiębiorstw, ma wpływ zarówno na strukturę klientów, jak i na kwalifikacje i dostęp do pracowników;

- zmiany w postrzeganiu - potrzeby ludzi i ich postrzeganie rzeczywistości zmienia się z pokolenia na pokolenie;

- nowa wiedza.

\section{RODZAJE INNOWACJI}

W literaturze istnieje wiele różnych klasyfikacji rodzajów innowacji. Jest to uwarunkowane celami, którym mają służyć, dlatego do podziału innowacji stosuje się rozmaite kryteria. Innowacje mogą dzielić się ze względu na:

- kryterium oryginalności zmian:

- innowacje kreatywne (twórcze, oryginalne) - to samodzielne i oryginalne odkrycia, które mają ogromne znaczenie w skali makro i mikroekonomicznej;

- innowacje imitujące (nieoryginalne, adaptowane, naśladowcze) powstają w wyniku naśladownictwa i rozpowszechnienia oryginalnych osiągnięć; rozszerzają skalę i zakres innowacji kreatywnych.

- zakres powodowanych skutków:

- innowacje strategiczne - realizują strategiczne cele społeczeństwa; dotyczą przedsięwzięć innowacyjnych o charakterze długofalowym, mają istotny wpływ na rozwój całego przedsiębiorstwa; 
- innowacje taktyczne - dotyczą zmian w wyrobach, technologii produkcji i organizacji pracy; ich głównym celem jest podniesienie sprawności funkcjonowania firmy, a także wprowadzenie nowych produktów i zaspokojenie potrzeb rynku.

- dziedzinę działalności:

- innowacje produktowe - wytworzenie nowych produktów lub udoskonalenie już wytworzonych;

- innowacje procesowe/technologiczne - dotyczą sposobu projektowania, produkowania i dostarczania produktu na rynek;

- innowacje organizacyjne - zwiększają wrażliwość firmy na jej otoczenie, umożliwiają skoordynowaną ekspansję rynkową przy jednoczesnym zachowaniu zdolności innowacji.

- stopień złożoności:

- innowacje sprzężone - są wynikiem współdziałania pewnej liczby osób, zespołów, organizacji gospodarczych i instytucji;

- innowacje niesprzężone - są wynikiem działalności twórczej oraz naśladowczej wykonanej przez pojedynczych racjonalizatorów, którzy sami je wprowadzają, wykorzystując jedynie własną wiedzę i własny kapitał.

- miejsce powstania:

- innowacje powstałe poza organizacją - przejmowane z zagranicy $\mathrm{w}$ postaci licencji, imitacji, tworzenie joint-ventures, korzystanie z franchisingu, opracowane przez placówki naukowo-badawcze, uczelnie wyższe;

- innowacje powstałe wewnątrz organizacji - powstają na podstawie badań własnych, pracy kadry kierowniczej i pracowników firmy.

- skutki:

- innowacje radykalne (duże, rewolucyjne) - wiążą się z przełomem technologiczno-organizacyjnym; występują bardzo rzadko, ponieważ wiążą się z dużym ryzykiem;

- innowacje usprawniające (małe, przyrostowe).

- kryterium stopnia nowości:

- innowacje stanowiące nowość w skali światowej, np. wszystkie wynalazki;

- innowacje stanowiące nowość w skali kraju, np. nowa produkcja wprowadzona na podstawie licencji;

- innowacje stanowiące nowość w skali firmy, np. projekty racjonalizatorskie. 


\section{PROCES WDRAŻANIA INNOWACJI}

Rosnące wymagania rynku powodują konieczność ciągłego reagowania na potrzeby i oczekiwania potencjalnych klientów. Działania te wymagają od przedsiębiorstwa prowadzenia określonej polityki innowacyjnej nie tylko popierającej innowacje i stymulującej ich wdrażanie oraz rozwój, ale również aktywnie oddziałującej na rynek i wykorzystującej zachodzące zmiany jako okazje do podejmowania nowych wyzwań.

Możliwość wdrażania innowacji jest w każdym przedsiębiorstwie ograniczona, ponieważ wymaga wysokich nakładów na prace badawczo-rozwojowe lub zakup licencji, a tym samym stanowi istotną barierę dla pozyskiwania i stosowania nowości. Na proces innowacyjny przedsiębiorstwa wpływa szereg różnych czynników. Ważną kwestią jest gotowość firmy na wprowadzanie zmian i innowacji w życie, gdyż nie wystarcza tutaj samo zaangażowanie kierownictwa firmy, ale potrzebna jest również motywacja pracowników, zrozumienie potrzeby zmiany i zaangażowanie się w jej realizację.

Zbigniew Chróścicki przedstawił kilka sprawdzonych sposobów wdrażania innowacji w firmie. Są to [Chróścicki, 1999, s. 21]:

- „zasada z góry do dołu”, która polega na analizie sytuacji wewnętrznej i powierzeniu zespołowi złożonemu z przedstawicieli kluczowych działów celów, które mają wskazywać kierunki zmian; zespół musi opracować podstawowe mierniki założonych celów, mogą one obejmować kryteria oceny pracowników;

- metoda „dośrodkowa” uwzględniająca całościowe procesy, co sprzyja odpowiednim korektom struktur i metod zarządzania zgodnie z filozofią utrzymywania dobrych stosunków z klientami, dostawcami i pracownikami; metoda ,dośrodkowa” stosowana jest przede wszystkim tam, gdzie kierownictwo dobrze zna słabe punkty rzutujące na jakość wyrobów, usług lub działań;

- filozofia „z dołu do góry” wykorzystywana jest w organizacjach, które osiągnęły już wysoki stopień dojrzałości, gdzie pracownicy są wyczuleni na problemy firmy i umieją je rozwiązywać;

- metoda „krok po kroku” oznacza stopniowe rozszerzanie działań; zwolennicy zmian z różnych szczebli hierarchii podejmują inicjatywy wykorzystujące istniejące już systemy oraz instrumenty, wyszukują sojuszników i zabiegają o poparcie kierownictwa dla szerszych działań. 
Z kolei B. C. Twiss wyróżnił osiem strategii wprowadzania innowacji. Są to strategia ofensywna, strategia defensywna, strategia zakupu licencji inaczej strategia „wchłaniania”, strategia unikania, strategia kreowania ryn$\mathrm{ku}$, strategia niezależna, strategia pozyskiwania personelu, strategia pozyskiwania innych firm [Penc, 1995, s. 89].

Wybierając odpowiednią strategię innowacyjną, przedsiębiorstwo musi uwzględniać szereg czynników, np. istniejące i przyszłe możliwości zbytu, zamierzenia innowacyjne konkurentów, potencjał ludzki, rzeczowy i finansowy, własne zaplecze naukowo-techniczne, poziom rozwoju technicznego.

\section{KONKURENCYJNOŚĆ FIRM INNOWACYJNYCH}

Przedsiębiorstwo, które chce zachować konkurencyjność i odnosić sukcesy, musi dokonywać wielu zmian, przekształcać swoją strukturę organizacyjną, szybko zmieniać wyroby, rynki i rodzaje działalności. Wdrażanie zmian i innowacji ożywia całą organizację, pobudza do działania i wymusza wzrost sprawności funkcjonowania firmy. Proces zmian stawia przed członkami organizacji nowe wyzwania, które pozytywnie wpływają na rozwój umiejętności i twórczego myślenia. Wprowadzane rozwiązania często wiążą się z koniecznością podnoszenia kwalifikacji pracowników lub ich zmianą, dzięki temu pracownicy lepiej poznają własne predyspozycje, zdolności i mogą skuteczniej pokierować swoim rozwojem zawodowym. Zmiana wymaga również usprawnienia przepływu informacji $\mathrm{w}$ organizacji. Stanowi szansę na poprawę wzajemnych relacji pomiędzy pracownikami. Ponadto organizacja, wprowadzając zmiany, gromadzi nowe doświadczenia i umiejętności, które mogą okazać się pomocne w dalszych zmaganiach $\mathrm{z}$ otoczeniem. Pomyślnie przeprowadzona zmiana sprawia, że organizacja chętniej otwiera się na wszelkie nowości. Wprowadzanie zmian wpływa także korzystnie na ogólny wizerunek. Organizacja zaczyna być postrzegana przez kontrahentów i konkurencję jako podmiot elastyczny, potrafiący odnaleźć się w nowej sytuacji, taki, który nie boi się ryzyka i podejmuje nowe działania w trosce o klientów. Zmiany i innowacje, oprócz licznych szans i korzyści, niosą ze sobą także zagrożenia. Zagrożenia te najczęściej pojawiają się w związku z brakiem przygotowania organizacji do wprowadzenia zmian lub w związku z nieodpowiednimi kompetencjami menedżerów. Głównym zagrożeniem jest możliwość przeprowadzenia błędnej oceny bieżącej sytuacji. Może to doprowadzić do 
określenia niewłaściwego obszaru lub kierunku zmian, a w konsekwencji do pogorszenia stanu organizacji. Zagrożenie dodatkowo potęguje związany ze zmianą chaos i destabilizacja. Współczesna organizacja powinna być świadoma szans i zagrożeń wynikających z decyzji dotyczących zmian i innowacji, dlatego musi dążyć do maksymalnego wykorzystania szans przy jednoczesnym ograniczeniu zagrożeń. Tylko takie działanie pozwoli efektywnie funkcjonować i rozwijać się organizacji. Tylko takie działanie pozwoli firmie budować konkurencyjną pozycję.

Niestety polskie firmy cechuje stosunkowo niski stopień innowacyjności. O niskiej innowacyjności naszych przedsiębiorstw świadczy fakt, że nasz kraj pod względem konkurencyjności zajmuje dopiero 43 miejsce na liście rankingowej sporządzonej przez odpowiednie instytucje międzynarodowe. Istnieje ścisły związek między stanem konkurencyjności wewnątrz kraju a zdolnością konkurencyjną kraju i firm za granicą. Podstawą konkurencyjności są nowoczesne technologie i produkty o najwyższej jakości, czego źródłem są właśnie innowacje. Tak więc należy dokładać wszelkich starań, by sukcesywnie podnosić poziom innowacyjności naszych przedsiębiorstw. Potrzebne są do tego wiedza, nakłady finansowe, ale przede wszystkim zaangażowanie ludzi.

\section{ZAKOŃCZENIE}

Zarządzanie współczesnymi przedsiębiorstwami staje się coraz bardziej złożone. Firmy muszą rozwiązywać coraz trudniejsze problemy, reagować szybko i elastycznie na zmieniające się warunki. Rynek i otoczenie stają się coraz bardziej wymagające i niepewne. Zmieniają się upodobania i gusta klientów, pojawiają się nowe technologie, sposoby produkcji. Zmieniają się także wewnętrzne warunki działania przedsiębiorstw i czynniki sukcesu. $\mathrm{Z}$ jednej strony przedsiębiorstwo musi być otwarte na rynek, dopasowując swoją produkcję do potrzeb otoczenia, dbać o terminowe i niezawodne zaspokajanie potrzeb rynkowych. $Z$ drugiej strony przedsiębiorstwo musi być otwarte na sprawy wewnętrzne związane z doskonaleniem swego potencjału, musi dbać o pracowników, tworzyć przyjazne warunki pracy, mobilizować do podnoszenia kwalifikacji. Wprowadzanie zmian wywołuje zawsze określone nadzieje i obawy. Każda bowiem zmiana burzy istniejący stan i porządek, narusza spoistość organizacyjną i wykreowany już poziom sprawności przedsiębiorstwa. Skuteczna realizacja zmian wymaga przełamywania oporu pracowników i pozyskiwania ich poparcia. Tak więc wdra- 
żanie zmian i innowacji musi stać się wyzwaniem dla menedżerów skutecznie realizujących wizję i misję organizacji. Spełnienie tych warunków stwarza bowiem przesłankę ku temu, aby osiągnąć sukces lub przynajmniej wyznaczyć drogę do sukcesu. A dla współczesnej organizacji sukcesem takim jest jej konkurencyjna pozycja na rynku.

\section{BIBLIOGRAFIA}

Armstrong M. (2001), Zarzadzanie zasobami ludzkimi, Dom Wydawniczy ABC, Kraków.

Baruk J. (2006), Zarzadzanie wiedza i innowacjami, Wydawnictwo Adam Marszałek, Torun.

Beer M., Nohria N. (2000), Kombinacja twardej i łagodnej filozofii zmian, „Zarządzanie na Świecie", nr 7.

Błaszczyk W. (2005), Metody organizacji i zarzadzania. Ksztattowanie relacji organizacyjnych, PWN, Warszawa.

Brzeziński M. (2001), Zarządzanie innowacjami technicznymi i organizacyjnymi, Difin, Warszawa.

Brzozowski M., Kopczyński T., Przeniczka J. (2001), Metody organizacji i zarzadzania, Wydawnictwo Akademii Ekonomicznej w Poznaniu, Poznań.

Carr D. K., Hard K. J., Trahant W. J. (1998), Zarzadzanie procesem zmian, Wydawnictwo Naukowe PWN, Warszawa.

Chróścicki Z. (1999), Zarządzanie firma, Wydawnictwo C.H. Beck, Warszawa.

Drucker P. (1992), Innowacja i przedsiębiorczość. Praktyka i zasady, PWE, Warszawa.

Drucker P. (2004), Natchnienie i fart czyli innowacja i przedsiębiorczość, Wydawnictwo Studio EMKA, Warszawa.

Griffin R. W. (2004), Podstawy zarzadzania organizacjami, PWE, Warszawa.

Grouard B., Meston F. (1997), Kierowanie zmianami w przedsiębiorstwie, Wydawnictwo Poltext, Warszawa.

Grudzewski W., Hejduk I. (2001), Projektowanie systemów zarządzania, Difin, Warszawa.

Janasz W., Kozioł K. (2007), Determinanty działalności innowacyjnej przedsiębiorstw, PWE, Warszawa.

Janasz W., Kozioł-Nadolna K. (2011), Innowacje w organizacji, PWE, Warszawa. 
Janasz W., Leśkiewicz I. (1995), Identyfikacja i realizacja procesów innowacyjnych $w$ przedsiębiorstwie, Wydawnictwo Naukowe Uniwersytetu Szczecińskiego, Szczecin.

Jasiński A. (1992), Przedsiębiorstwo innowacyjne na rynku, KiW, Warszawa.

Krishnan M., Prahalad C. (2010), Nowa era innowacji, PWN, Warszawa.

Krupa K. (2006), Teoria zmian organizacyjnych przedsiębiorstw ery informacji (wybrane aspekty i narzędzia), Wydawnictwo Uniwersytetu Rzeszowskiego, Rzeszów.

Krzywicka-Szpor K. (2002), Zarządzanie zmianq i okresem przejściowym, Wydawnictwo MT Biznes, Warszawa.

Marciniak S. (2000), Innowacje i rozwój gospodarczy, Kolegium Nauk Społecznych i Administracji Politechniki Warszawskiej, Warszawa.

Masłyk-Musiał E. (2003), Organizacje w ruchu, Oficyna Ekonomiczna, Kraków.

Mikołajczyk Z. (2002), Techniki organizatorskie w rozwiazywaniu problemów zarządzania, PWN, Warszawa.

Mikołajczyk Z. (2003), Zarządzanie procesem zmian w organizacji, Wydawnictwo Górnośląskiej Wyższej Szkoły Handlowej, Katowice.

Penc J. (1999), Innowacje i zmiany w firmie. Transformacja i sterowanie rozwojem przedsiębiorstwa, zasady dziatania, warunki sukcesu, Agencja Wydawnicza Placet, Warszawa.

Penc J. (1995), Strategie zarzadzania. Strategie dziedzinowe i ich realizacja. Zintegrowane zarzadzanie strategiczne, Agencja Wydawnicza Placet, Warszawa.

Perenc J., Hołub-Iwan J. (2011), Innowacje w rozwijaniu konkurencyjności firm. Znaczenie, wsparcie, przyklady zastosowań, C.H. Beck, Warszawa.

Pomykalski A. (1997), Innowacje, Politechnika Łódzka, Łódź.

Pomykalski A. (2001), Zarzadzanie innowacjami, Wydawnictwo Naukowe PWN, Warszawa-Łódź.

Sosnowska A., Łobejko S., Kłopotek A. (2000), Zarzadzanie firma innowacyjna, Difin, Warszawa.

Ścibiorek Z. (2005), Ludzie podczas zmian w organizacji, Wydawnictwo Adam Marszałek, Torun.

Ścibiorek Z. (2007), Zmiany w organizacji - moda czy konieczność?, Wydawnictwo Adam Marszałek, Torun.

Zarębska A. (2002), Zmiany organizacyjne w przedsiębiorstwie. Teoria i praktyka, Wydawnictwo Difin, Warszawa. 


\title{
ORGANIZATIONAL CHANGES AND INNOVATIONS AS A CONDITION OF BUILDING COMPETITIVE ADVANTAGE IN A CONTEMPORARY ENVIRONMENT
}

\begin{abstract}
The goal of this paper is to show the role and importance of changes and innovations in a contemporary organization. Businesses that function nowadays have to build their competitive advantage by using various advantages. One of the possibilities is to implement changes and innovations in the business that are accepted by employees. Contemporary organizations cannot achieve a sufficiently competitive position without such activities.
\end{abstract}

Keywords: change; innovation; competitiveness, environment. 